\title{
A review on the role of jamun, syzygium cumini skeels in the treatment of diabetes
}

\begin{abstract}
The diabetes has been increasing throughout the globe with an alarming rate due to lifestyle changes and it has become a global burden requiring attention of the most populated countries, where its incidence is ever increasing. There are two major type of diabetes type I which is an autoimmune disorder where the T lymphocytes are involved in the destruction of $\beta$-cells of the pancreas and it has genetic predisposition. Type I diabetes is quite common in the children and young population. The Type II diabetes is highly prevalent and $90 \%$ of the world's population is suffering from this disease. It is due to obesity and development of peripheral resistance to insulin accompanied by a malfunctioning pancreas. Several treatment options are available for the treatment of diabetes in modern medicine, which are aimed to control the blood sugar level. This review describes the use of different parts of Jamun, Syzygium cumini in the treatment of diabetes to control blood sugar and cholesterol levels. In different study systems
\end{abstract}

Keywords: Diabetes, Jamun, blood sugar, mice, rat, human
Volume II Issue 2 - 2018

Ganesh Chandra Jagetia
Hiran Magri, India

Correspondence: Ganesh Chandra Jagetia, 10, Maharana

Pratap Colony, Sector-13, Hiran Magri,

Udaipur-3|3002, India, Email: gc.jagetia@gmail.com

Received: March 31, 2018| Published: April II, 2018

\section{Introduction}

The diabetes is one of the leading health problem in the world. There are 425 million people around the world who have been suffering from diabetes in 2017. The Chinese population has the highest number of diabetic patients amounting to 114.4 million individuals suffering from the disease. India has the second largest number of diabetic patients, which are 72.9 million individuals during 2015. There has been around 50\% increase in the diabetic patients in India between 2005-2015. Diabetes is also a major health problem in the USA, which consists of the third largest population (32.2 million) of diabetic patients. ${ }^{1}$

The diabetic is a metabolic disorder characterized by hyperglycaemia and glucose intolerance. The malfunctioning of pancreas is the major cause of this metabolic disorder. This may be due to lack of insulin production, defective insulin action or both. The diabetes is four types depending on the aetiology and clinical presentation. The insulin dependent diabetes mellitus (IDDM, Type I) and non-insulin dependent diabetes mellitus (NIDDM, Type II). The other types of diabetes include gestational diabetes, and other specific types. ${ }^{2}$ The type I diabetes (IDDM) is an autoimmune disease produced due to the destruction of $\beta$-cells of islets of Langerhans by the body's $\mathrm{T}$ lymphocytes leading to local inflammation and suppression of insulin secretion and this needs insulin replacement therapy. ${ }^{3}$ It is more common in children than adults and has genetic predisposition and its incidence is on the rise. ${ }^{4}$ Type II diabetes is characterized by development of peripheral insulin resistance and impaired secretions of insulin by pancreas. It is more prevalent than type I. The individuals suffering from type II diabetes suffers from the intermediate stages of impaired fasting glucose and impaired glucose tolerance and therefore it is also known as prediabetes. Obesity is one of the leading causes of development of type-II diabetes and $90 \%$ of the diabetic patients belong to this category. ${ }^{5}$ The diabetes is the sixteenth leading cause of mortality worldwide. ${ }^{6}$ Diabetes is characterized by blurred visions, fatigue, hunger, excess thirst, polyurea and weight loss in the diabetic patients. ${ }^{7,8}$ Several treatment modalities are available for the treatment of both type I and II diabetes in the modern medicine. The diabetes leads to various other disorders including, cardiomyopathies, nephrotoxicity, neuropathy, cerebrovascular disorders and wound healing disorders. ${ }^{9}$ The global burden of treatment cost of diabetes is very high and alternative systems of medicine provide treatment choices to diabetic patients. The ancient system of medicine, the Ayurveda has also described its treatment and I am going to focus on the use of Jamun, Syzygium cumini in the treatment of diabetes.

\section{Jamun characteristics}

Jamun, Syzygium cumini belongs to Family: Myrtaceae and is also known as Eugenia cumini Druce; Eugenia caryophyllifolia Lam., Eugenia jambolana Lam., Eugenia djouat Perr., Syzygium caryophyllifolium (Lam.) DC., Syzygium jambolana (Lam.) DC., Syzygium jambolanum DC, Calyptranthes oneillii Lundell, Calyptranthes jambolana Willd. and Myrtus cumini L. (Figure 1). It is an indigenous plant to Indian subcontinent and it is commonly grows in India, Bangladesh, Ceylon, Pakistan, and Myanmar. Jamun is a rapidly growing tree, which is 100 feet tall and start fruiting in summer. ${ }^{10,11}$ The fruits are produced in clusters and each cluster consists of a few to 10 or 40 fruits. Jamun fruits are round to oblong in shape and $1 / 2$ to 2" long (Figure 1). The Jamun fruits are green coloured and turns from light to dark purple or even black after ripening. ${ }^{10,11}$ Their taste is sweetish sour and eating of Jamun fruits makes the tongue purple. The other names of Jamun are Indian blackberry, black plum, Duhat Jambu, Jaman, Jambul, Jambool, Java plum, Portuguese or Malabar plum. ${ }^{12,13}$ Jamun has several beneficial effects on many ailments. ${ }^{11}$ Despite this fact, Jamun may have some adverse effects, if eaten in excess or during certain conditions. Since it lowers blood sugar, it should be avoided before one week and a minimum of two weeks after surgery as it may have adverse effect on healing. Eating of Jamun empty stomach and also after drinking of milk may produce adverse effect. Breast feeding mothers and pregnant women should not eat Jamun. Eating of Jamun in excess amount may lead to cough, sputum accumulation in lungs, body ache and fever. ${ }^{11}$ 


\section{Jamun as antidiabetic agent}

Antidiabetic effect of Jamun has been indicated in Ayurvedic pharmacopeia, which states that the seed powder of Jamun is effective in controlling high blood sugar levels (Figure 1). Jamun has been used to control blood sugar levels for more than 130 years in West however, clinical studies are mixed results. Some of the patients had shown control of blood sugar levels after they have been put on Jamun therapy indicating a good response to the treatment, whereas others did not show any improvement after the treatment. ${ }^{14}$ The hypoglycaemic effect of different parts of Jamun to control diabetes in preclinical models have been investigated by several investigators who have shown that Jamun alleviates blood sugar levels (Table 1). These preclinical studies are with mixed results as a few studies have been negative where no hypoglycaemic effect of jamun was observed in alloxan-induced diabetic rats. ${ }^{15}$ However, majority of the preclinical reports have indicated that different parts of Jamun reduced blood sugar levels in rodent models of diabetes and clinical setting. The seed powder extracted in water has been shown to reduce blood sugar level in diabetic rabbits. ${ }^{16}$ The administration of aqueous seed extract of Jamun at a dose of $1 \mathrm{~g} / \mathrm{kg} \mathrm{b}$. wt. in diabetic rats has been reported to produce hypoglycaemic effect in the blood. ${ }^{17}$ Likewise, numerous other studies on aqueous seed extract has been found to reduce blood sugar in the diabetic rats. ${ }^{18-20}$ The lyophilized powder of aqueous seed extract has been reported to decrease the blood glucose level in diabetic mice and rats. ${ }^{21,22}$ Similarly, aqueous Jamun seed extract consisting of gummy fibres has been highly effective in controlling diabetes in alloxan induced diabetes in rats. However, in contrast, the aqueous extract devoid of gummy fibre did not have any effect ion blood sugar level. ${ }^{23}$ The alloxan-induced diabetic rats and rabbits administered with ethanol extract of Jamun seeds showed a decline in fasting blood glucose levels in an earlier study. ${ }^{24}$ Likewise, The Jamun seed kernel extracted in ethanol reduced the blood glucose level in the streptozotocin-induced diabetic rats and also restored the activities of catalase, glutathione peroxidase and superoxide dismutase enzymes accompanied by restoration of glutathione concentration in liver and kidney of diabetic rats. ${ }^{25}$ Administration of various doses of Jamun seed powder into streptozotocin-induced diabetic rats has shown an attrition in the fasting glucose level. ${ }^{26}$ Likewise, treatment of streptozotocin-induced diabetic rats with $100 \mathrm{mg} / \mathrm{kg}$ b. wt. seed kernel ethanol extract reduced the blood sugar level, urea and cholesterol and led to a rise in the glucose tolerance and decreased the glutamate oxaloacetate transaminase and glutamate pyruvate transaminase activities. ${ }^{27}$ An alleviation in the blood glucose level in the streptozotocin-induced diabetic rats have been reported after treatment with mycaminose isolated from Jamun and ethyl acetate and methanol extracts of Jamun seeds in an earlier study. ${ }^{28}$ The treatment of alloxan-induced diabetic mice and rats with Jamun seed methanol extract has been reported to alleviate serum glucose level earlier. ${ }^{29,30}$ The administration of ethanol extract of Jamun seeds depleted the blood serum glucose levels in the streptozotocin induced diabetic rats in some other studies. ${ }^{31,32}$ The sephadex gel separated of active principles from the ethanol fraction of seed extract of Jamun has been reported to decline the serum glucose level in the of alloxaninduced mild and severe diabetes in rats. ${ }^{33}$ The administration of streptozotocin-induced type -II diabetic rats with $400 \mathrm{mg} / \mathrm{kg}$ aqueous Jamun seed extract of has been found to bring the glucose level to almost normal level and it also increased the expression of PPAR $\gamma$ and PPAR $\alpha$ proteins in the rat liver. ${ }^{34}$ The aqueous Jamun seed extract has been reported to decrease serum glucose levels in the alloxan- induced diabetes in mice. ${ }^{35}$ Supplementation of Jamun seed powder in human diabetic subject for 30 days reduced the fasting and post prandial blood glucose levels. ${ }^{36}$ The aqueous and methanol extracts of root, stem bark, leaf and seed extracts of Jamun has been reported to lower serum glucose levels in alloxan-induced diabetes in male Sprague Dawley rats. ${ }^{37}$ Recently, the administration of ethanol extract of Jamun seeds and fruits for 60 days reduced serum glucose level in hyperglycaemic/diabetic rats and the former was more effective than the latter. ${ }^{38}$ In a study conducted on 60 Type -II diabetic individuals who were given Jamun seed powder in different forms for 60 days showed a significant reduction in the serum blood glucose and relief from the symptoms including fatigue, polyurea and tiredness. ${ }^{39}$ In a double blinded control clinical trial, feeding of $10 \mathrm{~g}$ of Jamun seed powder up to 90 days to diabetic patients reduced the fasting blood glucose levels by $9 \%, 18 \%$, and $30 \%$ and post prandial glucose by $8 \%, 15 \%$, and $22 \%$ after 30,60 , and 90 days, respectively. ${ }^{40}$

Table I The hypoglycaemic effect of different extracts of jamun, Syzygium cumini in preclinical and clinical setting

\begin{tabular}{|c|c|c|c|c|}
\hline S. No. & $\begin{array}{l}\text { Parts } \\
\text { used }\end{array}$ & $\begin{array}{l}\text { Extract } \\
\text { type }\end{array}$ & Species & Reference \\
\hline \multirow[t]{3}{*}{ I } & \multirow[t]{3}{*}{ Seed } & Aqueous & $\begin{array}{l}\text { Rabbit } \\
\text { Rat } \\
\text { Mice } \\
\text { Humans }\end{array}$ & $\begin{array}{l}16 \\
15,17- \\
20,23,24,34 \\
22,35 \\
36,39,40\end{array}$ \\
\hline & & Ethanol & $\begin{array}{l}\text { Rat \& Rabbit } \\
\text { Humans }\end{array}$ & $\begin{array}{l}25-28,31-33 \\
38\end{array}$ \\
\hline & & $\begin{array}{l}\text { Ethyl } \\
\text { acetate } \\
\text { Methanol }\end{array}$ & Rat and mice & $29,30,37$ \\
\hline \multirow[t]{2}{*}{2} & Fruit & Aqueous & Rat & $4 \mid-43$ \\
\hline & & Methanol & & 44 \\
\hline 3 & Stem & Ethanol & Rat & $37,45,46$ \\
\hline \multirow[t]{2}{*}{4} & Leaf & Aqueous & Humans & 47 \\
\hline & & Ethanol & Rat & 48 \\
\hline
\end{tabular}

Many studies conducted on the fruit pulp have also been found effective in treating diabetes in rodent model of diabetes. The treatment of streptozotocin-induced diabetic rats with the lyophilized fruit pulp extract of Jamun did not deplete higher blood sugar levels in a Brazilian study, ${ }^{41}$ whereas both aqueous and ethanol extracts of Jamun fruit pulp did lower the blood glucose in the alloxan-induced diabetic rats and the aqueous extract was superior than the ethanol extract. ${ }^{42}$ The aqueous Jamun fruit pulp extract has also been reported to lower the serum glucose level in streptozotocin-induced diabetes female Wistar rats however, the combination of Jamun fruit extract with the stem bark extract of Cinnamon zeylanicum was more effective than the either treatment alone. ${ }^{43}$ The methanol extract of Jamun fruit (pulp, seed, seed coat and kernel has been found to produce higher antidiabetic effect recently. ${ }^{44}$

Apart from the seed and fruit, the extract of stem bark of Jamun (Figure 1) was also found to be effective in reducing the blood glucose levels in spontaneous diabetic rats. ${ }^{45}$ The ethanol extract of Jamun bark has been also found to reduce blood glucose levels in rats. ${ }^{46}$ The aqueous leaf extract of Jamun alleviated the adenosine deaminase 
activity and glucose level in the serum of diabetic patients. ${ }^{47}$ A recent study on the oral administration of ethanol leaf extract of $100 \mathrm{mg} / \mathrm{kg} \mathrm{b}$. wt. of Jamun has been found to reduce insulin resistance and attenuate the blood glucose level in dexamethasone-induced diabetes in rats. ${ }^{48}$
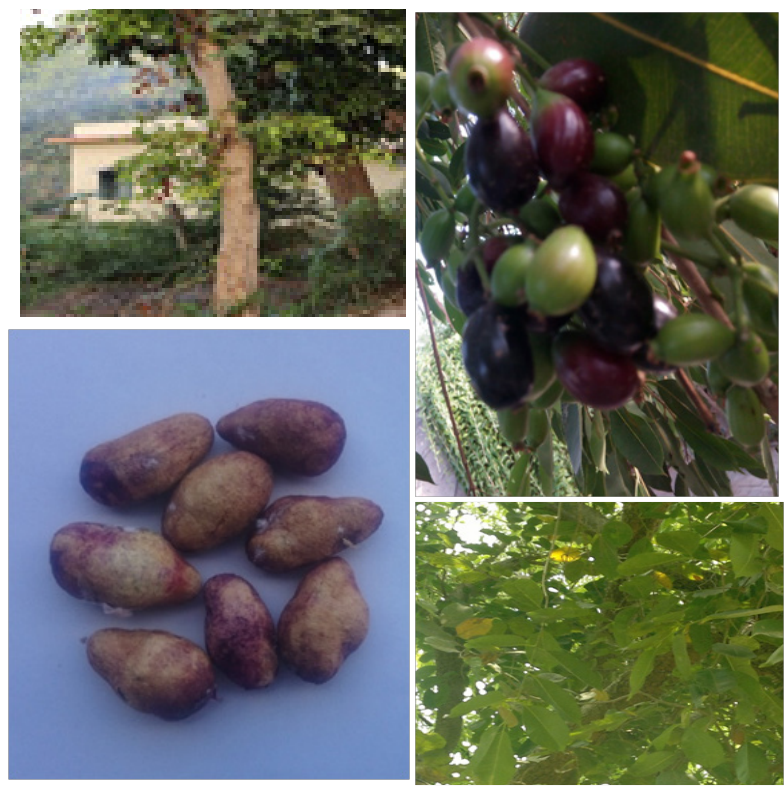

Figure I The images of various parts of jamun. Upper left: Jamun tree; Upper right: Fruits; Lower left: Seeds and Lower right: Leaves.

\section{Jamun as antihyperlipidemic agent}

The diabetes is usually associated with hyperlipidaemia (high cholesterol level) a consequence of insulin-resistant metabolic disarray, which is the main cause of cardiovascular disorder. Use of different parts of Jamun has been studied for their ability to attenuate blood cholesterol in different systems (Table 2). The seed extract of Jamun has been shown to cause an alleviation in the total serum cholesterol (TC)/high density lipoprotein cholesterol (HDL-c) ratio, amount of serum low density lipoprotein cholesterol (LDL-c) and the activity of HMG-CoA reductase in alloxan-induced diabetic rabbits. ${ }^{24}$ The ethanol extract of Jamun seed kernel has been found to reduce the (Low Density Lipoproteins) LDL and VLDL cholesterol levels in streptozotocin-induced diabetic rats, which was accompanied by an elevation in the HDL cholesterol. ${ }^{27}$ The aqueous Jamun fruit pulp extract has been reported to attenuate triglycerides and total cholesterol levels and elevate the HDL cholesterol level in the streptozotocin-induced diabetic rats. ${ }^{43}$ The active principles isolated by passing ethanol seed extract fraction of Jamun on sephadex gel did decrease triglycerides and total cholesterol and raised the HDL cholesterol level in the alloxan-induced diabetic rats..$^{33}$ In another study in mice the aqueous seed extract of Jamun has been found to reduce the hyperlipidaemic effect after alloxan treatment as indicated by the decline in the level of triglycerides and total cholesterol to normal level accompanied by a rise in the HDL cholesterol. ${ }^{35}$ The ethanol extract of seeds and fruits of Jamun has been found to reduce the higher levels of triglycerides and LDL and increase the HDL cholesterol in rats fed with high cholesterol diet. ${ }^{38}$ A study on human subject who were given seed powder for 60 days showed hypocholesterolemic effect.
Table 2 The hypolipidemic effect of different extracts of jamun, Syzygium cumini in preclinical models

\begin{tabular}{lllll}
\hline S. No. & Parts used & Extract type & Species & Reference \\
\hline I & Leaf & Aqueous & Humans & 47 \\
2 & \multirow{2}{*}{ Seed } & Rat & 37 \\
& & Aqueous & Rabbit & 24 \\
& & Ethanol & Rat & $27,33,38$ \\
3 & Fruit & Aquoeus & Rat & 35 \\
& & Ethanol & Rat & 42, \\
& & & Mice & 38,43 \\
\hline
\end{tabular}

The exact mechanism of action of Jamun in lowering the blood sugar and cholesterol level is not known. The Jamun may have employed several putative mechanisms to bring out its effects (Figure 2 ). The diabetes is triggered by induction of free radicals. Jamun may have reduced free radicals and improved the functioning of $\beta$-cells of pancreas reducing the sugar level. Jamun also stimulates the activation of different enzymes like catalase glutathione peroxidase, glutathiones-transferase and increased synthesis of glutathione and depletes lipid peroxidation that may have also helped to reduce the sugar cholesterol levels in the blood. Jamun may have reduced the activity of $\alpha$-amylase, which is upregulated in the diabetes. The $\alpha$-amylase activity has been found to be reduced by Jamun. ${ }^{44,49,50}$ At molecular level presence of Jamun may have upregulated the PPAR $\gamma$ and PPAR $\alpha$ leading to the suppressed activation of transcription factors including NF- $\mathrm{kB}$, nitric oxide synthase (iNOS), tumour necrosis factor-alpha (TNF- $\alpha$ ) and cyclooxygenases causing reduced inflammation and protection against diabetes and hyperlipidaemia. Apart from this Jamun may have also upregulated the transcription of Nrf2 leading to increase in the antioxidants that may have resulted in the proper functioning of $\beta$-cells of pancreas.

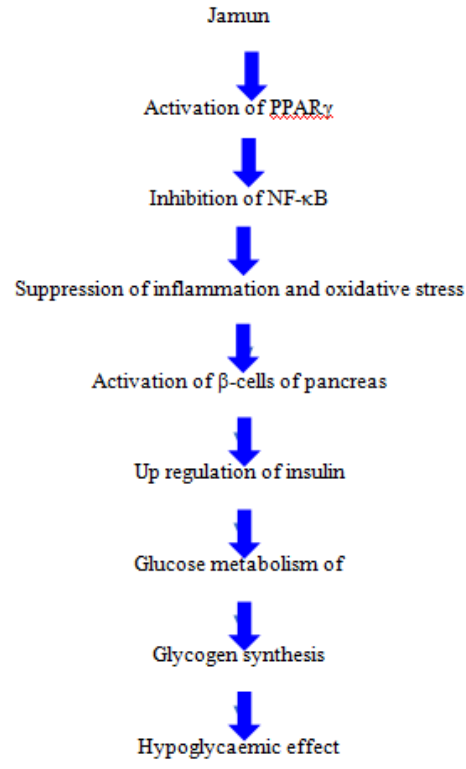

Figure 2 Antidiabetic action of Jamun 


\section{Conclusions}

The Jamun, Syzygium cumini belonging to family Myrtaceae has been used in traditional medicine for treatment of diabetes. The hypoglycaemic and hypolipidemic activities of Jamun may be due scavenging of free radicals as diabetes is caused by excess oxidative stress, elevated activities of catalase glutathione peroxidase, glutathione-s-transferase and increased synthesis of glutathione coupled with reduced lipid peroxidation. Jamun may have activated PPAR $\gamma$ and PPAR $\alpha$ genes that suppressed the transcription of NF- $\mathrm{kB}$, COX, iNOS, TNF- $\alpha$ and other inflammatory cytokines followed by the upregulation of Nrf2. However, there is need to systematically evaluate the molecular mechanisms of action of Jamun in various study systems

\section{Acknowledgment}

None

\section{Conflict of interest}

Author declares there is no conflict of interest.

\section{References}

1. IDF Diabetes Atlas, 2017. Global Picture. In: Karuranga S, Fernandes JR, Huang Y, Malanda B, ediotrs. $8^{\text {th }}$ ed. International Diabetes Federation. 2017:40-63.

2. Sicree R, Shaw J, Zimmet P. The Global Burden. Diabetes and Impaired Glucose Tolerance. Prevalence and Projections. In: Gan D. editor. Diabetes Atlas. 3rd ed. Brussels: International Diabetes Federation; 2006. p. 16-103.

3. McCrimmon RJ, Sherwin RS. Hypoglycemia in type 1 diabetes. Diabetes. 2010;59(10):2333-2339.

4. You WP, Henneberg M. Type 1 diabetes prevalence increasing globally and regionally: the role of natural selection and life expectancy at birth. BMJ Open Diabetes Res Care. 2016;4(1):e000161.

5. Herman WH, Zimmet P. Type 2 diabetes: an epidemic requiring global attention and urgent action. Diabetes Care. 2012;35(5):943-944.

6. Murray CJ, Lopez AD. Mortality by cause for eight regions of the world: Global Burden of Disease Study. Lancet. 1997;349(9061):1269-1276.

7. Expert Committee on the Diagnosis and Classification of Diabetes Mellitus. Report of the expert committee on the diagnosis and classification of diabetes mellitus. Diabetes Care. 2009;32(Suppl 1):s62-s67.

8. Singh R, Teel C, Sabus C, et al. Fatigue in type 2 diabetes: impact on quality of life and predictors. PloS One. 2016;11(11):e0165652.

9. Asif M. The prevention and control the type-2 diabetes by changing lifestyle and dietary pattern. $J$ Educ Health promot. 2014;3:1.

10. Morton J, Jambolan. In: Morton JF, editor. Fruits of warm climates. 1987. p. $375-378$.

11. Jagetia GC. Phytochemical composition and pleotropic pharmacological properties of Jamun, Syzygium cumini Skeels. J Explor Res Pharmacol. 2017;2(2):54-66.

12. Benthall AP. Trees of Calcutta and Its Neighborhood. Calcutta: Thacker, Spink \& Co; 1946.

13. Dastur JF. Useful Plants of India and Pakistan. 2nd ed. Bombay: D. B. Taraporevala Sons \& Co., Ltd; 1951.
14. Helmstädter A. Syzygium cumini (L.) SKEELS (Myrtaceae) against diabetes -125 years of research. Pharmazie. 2008;63(2):91-10.

15. Wastl H, Boericke GW, Foster WC. Studies of effects of Syzygium jambolanum on alloxan-diabetic rats. Arch Int Pharmacodyn. 1947;75: $33-50$.

16. Brahmachari HD, Augusti KT. Hypoglycemic agents from Indian indigenous plants. J Pharm Pharmacol. 1961;13:381-182.

17. Kedar P, Chakrabarti CH. Effects of Jambolan seed treatment on blood sugar, lipids and urea in streptozotocin induced diabetes in rabbits. Ind $J$ Physiol Pharmacol. 1983;27(2):135-140.

18. Bhaskaran Nair R, Santhakumari G. Anti-diabetic activity of the seed kernel of Syzygium cumini Linn. Ancient Sci Life 1986;6(2):80-84.

19. Achrekar A, Kaklij GS, Pote MS, et al. Hypoglycemic activity of Eugenia jambolana and Ficus bengalensis: mechanism of action. In vivo 1991;5(20:143-147.

20. Prince PS, Menon VP, Pari L. Hypoglycemic activity of Syzigium cumini seeds: effect on lipid peroxidation in alloxan diabetic rats. $J$ Ethnopharmacol. 1998;61(1):1-7.

21. Vikrant V, Grover JK, Tandon N, et al. Treatment with extracts of Momordica charantia and Eugenia jambolana prevents hyperglycemia and hyperinsulinemia in fructose fed rats. $J$ Ethnopharmacol. 2001;76:139-143.

22. Grover JK, Vats V, Rathi SS, et al. Traditional Indian anti-diabetic plants attenuate progression of renal damage in streptozotocin induced diabetic mice. J Ethnopharmacol. 2001;76(3):233-238.

23. Pandey M, Khan A. Hypoglycaemic effect of defatted seeds and water soluble fibre from the seeds of Syzygium cumini (Linn.) skeels in alloxan diabetic rats. Indian J Exp Biol. 2002;40(10):1178-1182.

24. Sharma SB, Nasir A, Prabhu KM, et al. Hypoglycaemic and hypolipidemic effect of ethanolic extract of seeds of Eugenia jambolana in alloxaninduced diabetic rabbits. $J$ Ethnopharmacol. 2003;85(2-3):201-206.

25. Ravi K, Ramachandran B, Subramanian S. Protective effect of Eugenia jambolana seed kernel on tissue antioxidants in streptozotocin-induced diabetic rats. Biol Pharm Bull. 2004;27(8):1212-1227.

26. Sridhar SB, Sheetal UD, Pai MR, et al. Preclinical evaluation of the antidiabetic effect of Eugenia jambolana seed powder in streptozotocindiabetic rats. Braz J Med Biol Res. 2005;38(3):463-468.

27. Ravi K, Rajasekaran S, Subramanian S. Antihyperlipidemic effect of Eugenia jambolana seed kernel on streptozotocin-induced diabetes in rats. Food Chem Toxicol. 2005;43(9):1433-439.

28. Kumar EK, Mastan SK, Reddy KR, et al. Anti-arthritic property of methanolic extract of Syzygium cumini seeds. Int J Integr Biol. 2008;4(1):55-61.

29. Chaturvedi A, Bhawani G, Agarwal PK, et al. Antidiabetic and antiulcer effects of extract of Eugenia jambolana seed in mild diabetic rats: study on gastric mucosal offensive acid-pepsin secretion. Indian $J$ Physiol Pharmacol. 2009;53(2):137-146.

30. Jonnalagadda A, Maharaja KK, Prem Kumar N. Combined effect of Syzygium cumini seed kernel extract with oral hypoglycemics in diabetes induced increase in susceptibility to ulcerogenic stimuli. $J$ Diabetes Metab. 2012;4(1):236.

31. Mastan SK, Latha TB, Latha TS, Srikanth A, Chaitanya GKumar KE. Influence of methanolic extract of Syzygium cumini seeds on the activity of gliclazide in normal and alloxan-induced diabetic rats. Pharmacologyonline. 2009;3:845-850. 
32. Yadav D, Lalti A, Singh S, et al. Evaluation of antidiabetic and phytochemical activity of $50 \%$ methanolic extract of jamun seed (Syzygium cumini). Search Res. 2013;4(3):13-16.

33. Sharma SB, Tanwar RS, Nasir A, et al. Antihyperlipidemic effect of active principle isolated from seed of Eugenia jambolana on alloxaninduced diabetic rabbits. J Med Food. 2011;14(4):353-359.

34. Sharma AK, Bharti S, Kumar R, et al. Syzygium cumini ameliorates insulin resistance and $\beta$-cell dysfunction via modulation of PPAR, dyslipidemia, oxidative stress, and TNF- $\alpha$ in type 2 diabetic rats. J Pharmacol Sci. 2012;119(3):205-213.

35. Siddiqui MS, Sharma B, Ram G. Anti-hyperglycemic and antihyperlipemia effects of Syzygium cumini seed in alloxan induced diabetes mellitus in Swiss albino mice (Mus musculus). Med Aromat Plants. 2014;3(4):166.

36. Ayya N, Nalwade V, Khan, TN. Effect of Jamun (Syzygium cumini L.) seed powder supplementation on blood glucose level of type-II diabetic subject. Food Sci Res J. 2015;6(2):353-356.

37. Deb L, Bhattacharjee C, Shetty SR, et al. Evaluation of anti-diabetic potential of the Syzygium cumini (Linn) skeels by reverse pharmacological approaches. Bull Pharmaceut Res.2013;3(3):135-145.

38. Raza A, Butt MS, Suleria HA. Jamun (Syzygium cumini) seed and fruit extract attenuate hyperglycemia in diabetic rats. Asian Pacific Journal of Tropical Biomedicine. 2017;7(8):750-754.

39. Banu H, Jyothi A. Hypoglycemic and hypocholesterolemic effect of Eugenia jambolana (kala jamun) spicy mix on type II diabetic subjects. Imperial J Interdiscipl Res. 2016;2(4):850-857.

40. Sidana S, Singh VB, Meena BL, et al. Effect of Syzygium cumini (jamun) seed powder on glycemic control: A double-blind randomized controlled trial. J Med Soc. 2017;31(3):185.

41. Pepato MT, Mori DM, Baviera AM, et al. Fruit of the jambolan tree (Eugenia jambolana Lam.) and experimental diabetes. J Ethnopharmacol. 2005;96(1-2):43-48
42. Sharma SB, Nasir A, Prabhu KM, et al. Antihyperglycemic effect of the fruit-pulp of Eugenia jambolana in experimental diabetes mellitus. $J$ Ethnopharmacol. 2006;104(3):367-373.

43. Rekha N, Balaji R, Deecaraman M. Antihyperglycemic and antihyperlipidemic effects ofextracts of the pulp of Syzygium cumini and bark of Cinnamon zeylanicum in streptozotocin-induced diabetic rats. $J$ Appl Biosci. 2010;28:1718-1730.

44. Gajera HP, Gevariya SN, Hirpara DG, et al. Antidiabetic and antioxidant functionality associated with phenolic constituents from fruit parts of indigenous black jamun (Syzygium cumini L.) landraces. J Food Sci Technol. 2017;54(10):3180-3191

45. Chirvan-Nia MM, Ratsimamanga AR. Re'gression de la cataracte et de l'hyperglyce'nie chez le Rat de sable (Psammomys obesus) diabe'tique ayant recu un extrait de Eugenia jambolana (Lamarck). C R Acad. Sci Hebd Seances Acad Sci D. 1972;274:1514-1516.

46. Ratsimamanga AR, Loiseau A, Ratsimamanga-Urveg S, et al. Nouvelle contribution a' l'e'tude de l'action d'un principe hypoglyce 'miant mis en e'vidence dans l'e'corce jeune de Eugenia jambolana (Myrtace'es) sur l'hyperglyce'mie provoque'e du lapin mormal et poursuite de sa purification. C. R. Acad. Sci Hebd Seances Acad Sci D. 1973;277:2219 2222.

47. Bopp A, De Bona KS, Bellé LP, et al. Syzygium cumini inhibits adenosine deaminase activity and reduces glucose levels in hyperglycemic patients. Fundam Clin Pharmacol. 2009;23(4):501-507.

48. Chattu M. Evaluation of antidiabetic activity for ethanolic extract of Syzygium cumini leaf in dexamethasone induced diabetic rats. Res Pharm Hlth Sci 2016;2(2):85-90.

49. Fatema F, Khan ZH, Khan ND, et al. Determination of amylase activity from germinated Syzygium cumini seed (jamun). IJAR. 2017;3(1):573575.

50. Prabakaran K, Shanmugavel G. Antidiabetic Activity and Phytochemica Constituents of Syzygium cumini Seeds in Puducherry Region, South India. Int J Pharmacogn Phytochem Res. 2017;9(7);985-989. 